\title{
Antithrombotic and Antioxidant Activity of Amaranth Hydrolysate Obtained by Activation of an Endogenous Protease
}

\author{
Ana Clara Sabbione ${ }^{1,2,3}$ - Sabrina M. Ibañez ${ }^{2}$ E. Nora Martínez ${ }^{1,2,3}$. \\ María Cristina Añón ${ }^{1,2,3}$ • Adriana A. Scilingo ${ }^{1,2}$
}

Published online: 29 March 2016

(C) Springer Science+Business Media New York 2016

\begin{abstract}
Ingestion of diets with antithrombotic and antioxidant components offer a convenient and effective way to prevent and reduce the incidence of cardiovascular diseases. The aim of the present work was to obtain an amaranth hydrolysate by the activation of an endogenous aspartic protease, to establish adequate experimental conditions, and to evaluate its antithrombotic and antioxidant activity in order to assess its potential application as an ingredient in functional foods. The results obtained not only confirmed the presence of an endogenous protease in the amaranth isolate, but also allowed us to select an adequate incubation conditions $\left(\mathrm{pH} \mathrm{2,} 40^{\circ} \mathrm{C}, 16 \mathrm{~h}\right)$. The hydrolysate obtained (degree of hydrolysis $5.3 \pm 0.4 \%$ ) showed potential antithrombotic activity $\left(\mathrm{IC}_{50}=5.9 \pm 0.1 \mathrm{mg}\right.$ soluble protein $\left./ \mathrm{mL}\right)$ and had more antioxidant activity than the isolate, indicating that the activation of the protease released bioactive peptides from amaranth proteins. Decreasing the $\mathrm{pH}$ is a simple and cheap process and is another way to obtain potential functional ingredients with bioactive compounds.
\end{abstract}

Electronic supplementary material The online version of this article (doi:10.1007/s11130-016-0540-y) contains supplementary material, which is available to authorized users.

Adriana A. Scilingo

aascilingo@gmail.com

1 Centro de Investigación y Desarrollo en Criotecnología de Alimentos (CIDCA), Calle 47 y 116, 1900 La Plata, Argentina

2 Facultad de Ciencias Exactas, Universidad Nacional de La Plata, La Plata, Argentina

3 CONICET (Consejo Nacional de Investigaciones Científicas y Técnicas), CCT-La Plata, La Plata, Argentina
Keywords Amaranth proteins · Endogenous aspartic protease $\cdot$ Bioactive peptides $\cdot$ Antithrombotic and antioxidant activity
Abbreviations
DH\% Degree of hydrolysis
$\mathrm{IC}_{50}$ Concentration of isolate or hydrolysate that inhibits $50 \%$ of the thrombus formation or produces $50 \%$ radical neutralization
$\mathrm{H}_{\mathrm{EP}} \quad$ Hydrolysate prepared by activation of endogenous protease

\section{Introduction}

Food is considered functional if it contains a component, nutrient or not, which benefits a limited number of functions in the body providing welfare and health, understood as reducing the risk of disease [1]. In this context, functional foods contain components of different nature with proven physiological activity known as bioactive species; among them peptides encrypted in the sequences of proteins. Over the last years, it has been demonstrated a clear tendency in the use of peptides derived from food proteins due to its relevant functionality to human health [2]. Numerous studies proved that peptides derived from diverse sources which were released by exogenous proteases, fermentation processes or endogenous enzymes, showed antimicrobial, antihypertensive, hypocholesterolemic, antioxidant, antithrombotic, antiproliferative and immunomodulatory activity, among others [3-5]. In recent years, different researchers have found biological activities of proteins and peptides contained in amaranth seeds [6-9], making this pseudocereal an interesting source for its use in functional food ingredients. 
Due to the fact that cardiovascular diseases are among the main causes of death in the world, the consumption of foods containing antioxidant and/or antithrombotic compounds could be a strategy to implement as a possible way to decrease the incidence of these pathologies.

Studies performed in our laboratory showed the presence of an endogenous protease in amaranth protein isolates which was active at acid $\mathrm{pH}$ [10]. This finding led us to the idea of setting a process capable to generate amaranth hydrolysates by acidifying an isolate dispersion, as a way to release potential bioactive components. The presence of proteases in the seeds is very common, since they are involved in many aspects of physiology and development of the plant. These enzymes hydrolyze and mobilize reserve proteins, so they can be used as a nitrogen source by the seeds upon germination $[11,12]$.

In this context, the aim of this study was to obtain an amaranth hydrolysate by the activation of the endogenous protease to establish adequate experimental conditions and to evaluate its antithrombotic and antioxidant activity. In this regard, the potential application in the development of functional foods will be determined.

\section{Materials and Methods}

\section{Plant Materials and Samples Preparation}

Seeds of Amaranthus hypochondriacus (cv mercado) were harvested at Córdoba, Argentina, ground (cyclone mill, $1 \mathrm{~mm}$ mesh) and screened (0.092 $\mathrm{mm}$ mesh). The resulting flour was defatted with n-hexane at room temperature (ratio $1: 10$ ) during $24 \mathrm{~h}$, dried at room temperature, and stored at $0{ }^{\circ} \mathrm{C}$ until use.

Amaranth protein isolate was obtained as described by Martínez and Añón [13]. Briefly, amaranth defatted flour was suspended in distilled water $(10 \mathrm{~g}$ defatted flour $/ 100 \mathrm{~mL}, \mathrm{pH} 9$, $1 \mathrm{~h}$ stirring, room temperature). Centrifugation at $9000 \times \mathrm{g}$, $10^{\circ} \mathrm{C}, 20 \mathrm{~min}$ was made and the supernatant was adjusted to isoelectric point in order to precipitate the proteins ( $\mathrm{pH} 5)$. The precipitate obtained after centrifugation at $9000 \times g, 4{ }^{\circ} \mathrm{C}$, $20 \mathrm{~min}$, was suspended in water, neutralized and lyophilized.

\section{Selection of Conditions to Prepare Amaranth Protein Hydrolysate by Activation of an Endogenous Protease $\left(\mathrm{H}_{\mathrm{EP}}\right)$}

Assays modifying $\mathrm{pH}$, temperature and incubation time were performed (Fig. 1). The isolate was suspended in water $(20.4 \pm 0.3 \mathrm{mg} / \mathrm{mL})$ and different aliquots were used to study $\mathrm{pH}$ effect for $3 \mathrm{~h}$ at $40{ }^{\circ} \mathrm{C}(\mathrm{pH} 1.5 ; 2.0 ; 2.5 ; 3.0 ; 3.5 ; 4.0)$, temperature effect for $3 \mathrm{~h}$ and $\mathrm{pH} 2.0\left(25^{\circ} \mathrm{C}, 40^{\circ} \mathrm{C}, 55^{\circ} \mathrm{C}\right.$, $\left.65^{\circ} \mathrm{C}\right)$, and incubation time effect at $\mathrm{pH} 2.0$ and $40^{\circ} \mathrm{C}(1,3,5$, $7 \mathrm{y} 16 \mathrm{~h})$. The proteolysis was conducted at constant agitation and was stopped at $85^{\circ} \mathrm{C}$ for $10 \mathrm{~min}$. Samples were stored at $-20{ }^{\circ} \mathrm{C}$ until use. After establishing the adequate $\mathrm{pH}$, temperature and time conditions, $\mathrm{H}_{\mathrm{EP}}$ was obtained, freeze-dried, ground and stored at $0{ }^{\circ} \mathrm{C}$ until use.

\section{Samples Characterization}

\section{Centesimal Composition}

Protein content was determined by Kjeldahl method, using the conversion factor $5.85 \mathrm{~g}$ protein $/ \mathrm{g}$ nitrogen [14], water content by drying in a stove at $105^{\circ} \mathrm{C}$ until constant weight and ashes content was obtained by heating in a muffle at $550^{\circ} \mathrm{C}(\mathrm{AOAC}$ methods 954.01, 923.03, and 925.09; 1990). Carbohydrates and fiber content was calculated by difference.

\section{Electrophoresis SDS-PAGE and Tricine-SDS-PAGE}

SDS-PAGE runs were carried out in stacking and separating gels containing 40 and $120 \mathrm{~g} / \mathrm{L}$ acrylamide, respectively [15], and tricine-SDS-PAGE runs were carried out in stacking, spacing and separating gels using 160, 100 and $40 \mathrm{~g} / \mathrm{L}$ acrylamide, respectively [16]. Runs were performed under reducing conditions (sample buffer with $50 \mathrm{~mL} / \mathrm{L}$ of 2-mercaptoethanol, 2ME). Gels were fixed and stained with Coomassie Brilliant Blue R-250 (Anedra, San Fernando, Argentina) stain. Gels images were analyzed with Image $J$ in order to determine the molecular masses of the peptides and polypeptides, and the relative intensity of the bands. Electrophoretic runs were performed in duplicate.

\section{Degree of Hydrolysis (DH\%)}

The o-phthaldialdehyde method (OPA, Sigma, St. Louis, MO, USA) described by Nielsen et al. [17] was employed to quantify free amino groups. The following expression was used in order to calculate the $\mathrm{DH} \%$ :

$\mathrm{DH} \%=\left(\mathrm{NH}_{2} \mathrm{t}-\mathrm{NH}_{2} \mathrm{to}\right) /\left(\mathrm{NH}_{2}\right.$ to $\left.-\mathrm{NH}_{2} \mathrm{to}\right) \times 100$

$\mathrm{NH}_{2}$ t, $\mathrm{NH}_{2}$ to, and $\mathrm{NH}_{2}$ to: free amino groups at time $\mathrm{t}$, initial time (0) and infinite time of hydrolysis, respectively. $\mathrm{NH}_{2}$ to was determined experimentally from a nonhydrolyzed isolate, and $\mathrm{NH}_{2}$ to was obtained using the following expression:

$\mathrm{NH}_{2}$ to $=\left(1 / \mathrm{MW}_{\text {aa }}\right) \times\left(1+\mathrm{f}_{\text {Lys }}\right) \times \mathrm{P} \times 1000$

$\mathrm{MW}_{\mathrm{aa}}$ is the average molecular weight of the amino acids of amaranth proteins, $130 \mathrm{~g} / \mathrm{mol}_{\mathrm{Lys}}$ is the lysine proportion in amaranth proteins, 1/16 [14].

$\mathrm{P}$ is the protein concentration [18]. 


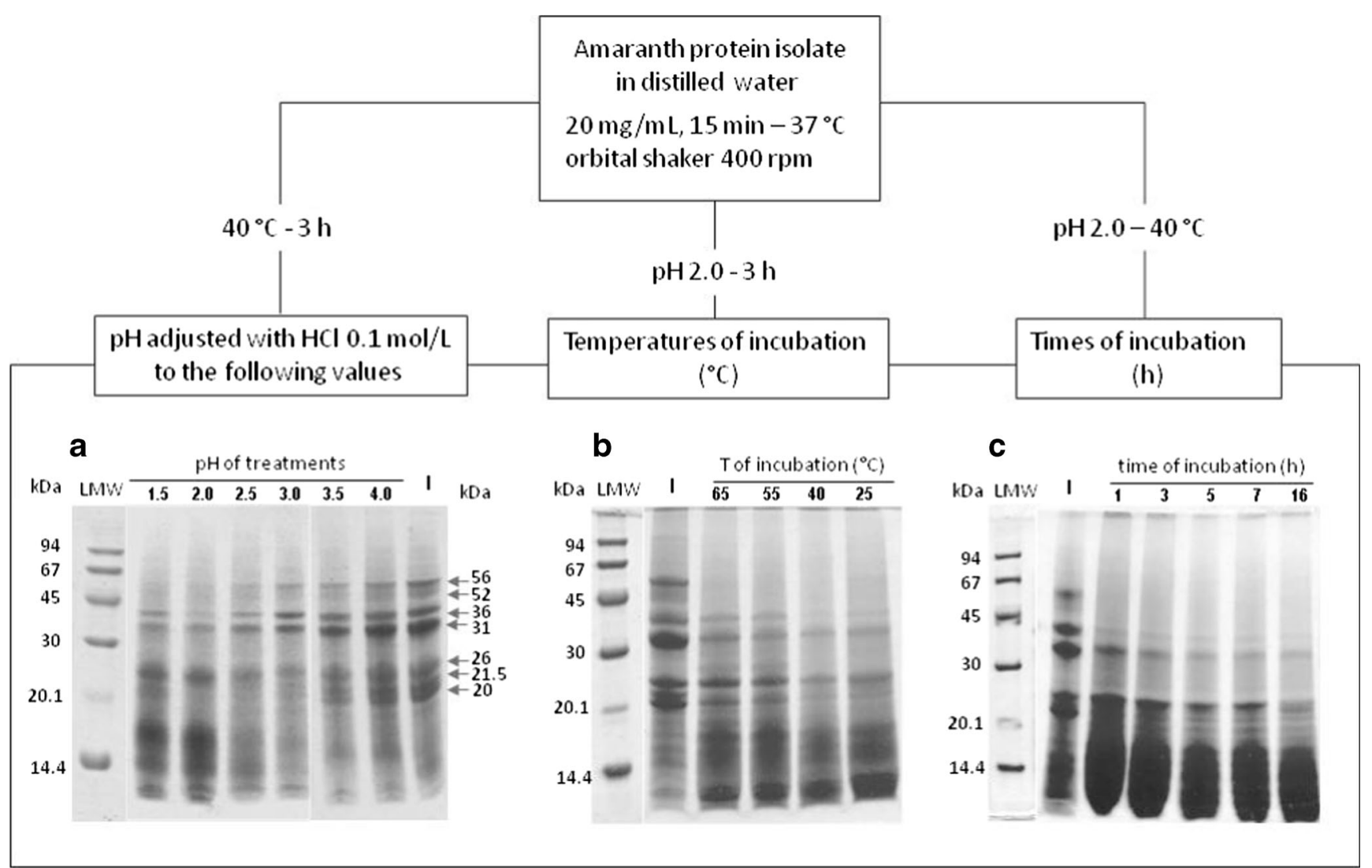

Fig. 1 Design of exploratory experiences to determine the best conditions to obtain the amaranth hydrolysate. Electrophoresis SDSPAGE in presence of 2-ME of amaranth protein isolate (I) at $\mathrm{pH} 7$. a Isolate treated at different $\mathrm{pHs}$ during $3 \mathrm{~h}$ at room temperature. $\mathbf{b}$ Isolate treated at $\mathrm{pH} 2$ during $3 \mathrm{~h}$ at different incubation temperatures. $\mathbf{c}$ Isolate

\section{Molecular Exclusion Chromatography}

Soluble fractions were analyzed in a Pharmacia LKB (Uppsala, Sweden), FPLC System, using the molecular exclusion column (GE- Healthcare total volume, $\mathrm{Vt}=25 \mathrm{~mL}$ ) Superose- $6 \mathrm{~N}^{\circ} 3$ (range: $5-5000 \mathrm{kDa}$ ). It was calibrated with blue dextran (void volume, Vo $=7.16 \mathrm{~mL}$ ), thyroglobulin $(669 \mathrm{kDa})$, alcohol dehydrogenase $(150 \mathrm{kDa})$, albumin $(67 \mathrm{kDa})$, ovoalbumin $(44 \mathrm{kDa})$, and ribonuclease $(19 \mathrm{kDa})$ from GE Healthcare. The molecular masses of the fractions were calculated using the equation:

$\log \mathrm{MW}=-0.2526 \mathrm{~V}_{\mathrm{e}}+5.976$

where MW is the molecular weight in $\mathrm{kDa}$ and $\mathrm{V}_{\mathrm{e}}$ is the elution volume in $\mathrm{mL}$.

Soluble fractions were obtained by dissolving the sample in buffer $28 \mathrm{mmol} / \mathrm{L} \mathrm{Na}_{2} \mathrm{HPO}_{4}, 7 \mathrm{mmol} / \mathrm{L} \mathrm{NaH} \mathrm{PO}_{4}, \mathrm{pH} 7.8$ and incubating it for $1 \mathrm{~h}$ at $25^{\circ} \mathrm{C}$ with agitation. Samples were then centrifuged at $10,000 \times \mathrm{g}$ for $30 \mathrm{~min}$ at $15^{\circ} \mathrm{C} .200 \mu \mathrm{L}$ of the soluble fraction were loaded in the column and eluted in the same buffer at $0.2 \mathrm{~mL} / \mathrm{min}$. Polypeptides and peptides treated at $\mathrm{pH} 2$ at room temperature during 1 to $16 \mathrm{~h}$. Variables are indicated in each line. LMW: standards low molecular weight: phosphorylase-b (94 kDa); bovine serum albumin (67 kDa); ovalbumin (45 kDa); carbonic anhydrase (30 kDa); trypsin inhibitor (20.1 kDa); $\alpha$ lactalbumin $(14.4 \mathrm{kDa})$

were detected by absorbance at $280 \mathrm{~nm}$. Every determination was performed at least twice.

Percentage areas of the peaks were calculated by determining the total area of each chromatogram and the area of every peak obtained. These data was processed with the Origin 8.0 program, peak analyzer function.

\section{Antithrombotic Activity}

The ability to inhibit the coagulation of fibrinogen was measured according to Yang et al. [19], and modified by Zhang et al. [20] with the microplate method. Briefly, in a microplate were added $140 \mu \mathrm{L}$ of $0.1 \mathrm{~g} / 100 \mathrm{~mL}$ fibrinogen (Sigma), and $40 \mu \mathrm{L}$ of amaranth isolate and its hydrolysate solubilized at different concentrations, buffer as a negative control of the coagulation inhibition or $0.3 \mathrm{mg} / \mathrm{mL}$ heparin (Abbott, Alameda, CA, USA) as a positive control of the coagulation inhibition. The clotting process was initiated with the addition of $10 \mu \mathrm{L}$ of thrombin (12 UI/mL, Sigma) and absorbance at $405 \mathrm{~nm}$ was measured before and after $10 \mathrm{~min}$ of adding the enzyme in a microplate reader Synergy HT-Siafrt ${ }^{\mathrm{TM}}$ (Biotek 
Instruments, USA). The inhibitory effects were calculated according to the following equation:

$\%$ Inhibition $=[(\mathrm{C}-\mathrm{CB})-(\mathrm{S}-\mathrm{SB})] /(\mathrm{C}-\mathrm{CB}) \times 100$

where, $\mathrm{CB}$ (control blank) is the initial absorbance of the negative control of inhibition, $\mathrm{C}$ (control) is the absorbance of the negative control at $10 \mathrm{~min}$ of incubation with thrombin, SB (sample blank) is the initial absorbance of the sample, and $\mathrm{S}$ (sample) is the absorbance of the sample at 10 min of incubation with thrombin.

Solution of the samples in the buffer $50 \mathrm{mmol} / \mathrm{L}$ Tris- $\mathrm{HCl}$, $\mathrm{pH} 7.2,0.12 \mathrm{mmol} / \mathrm{L} \mathrm{NaCl}$ were prepared, and incubated for $1 \mathrm{~h}$ at $25^{\circ} \mathrm{C}$ with agitation. Samples were then centrifuged at $10,000 \times \mathrm{g}$ for $30 \mathrm{~min}$ at $15^{\circ} \mathrm{C}$. The protein content in the supernatant was determined by the Lowry colorimetric method [18].

\section{Antioxidant Activity}

Oxygen Radical Absorbance Capacity (ORAC). The ORAC assay was performed in a 96-well black microplate, according to Orsini Delgado et al. [21]. Briefly, $150 \mu \mathrm{L}$ of $53.3 \mathrm{nM}$ fluorescein solution (Sigma) in $35 \mathrm{mmol} / \mathrm{L}$ phosphate buffer pH 7.8 were mixed with $25 \mu \mathrm{L}$ of sample, phosphate buffer (negative control) or Trolox (6-hydroxy-2,5,7,8tetramethylchroman-2-carboxylic acid Sigma, 6.25$75.0 \mu \mathrm{mol} / \mathrm{L}$, positive control). After $10 \mathrm{~min}$ incubation at $37{ }^{\circ} \mathrm{C}, 25 \mu \mathrm{L}$ of $160 \mathrm{mmol} / \mathrm{L}$ AAPH (2,2'-azo-bis-(2methyilpropionamidine) dihydrochloride, Sigma) were added and the microplate was incubated for $45 \mathrm{~min}$ at $37^{\circ} \mathrm{C}$, while fluorescence intensity $\left(\lambda_{\text {exc }}: 485, \lambda_{\text {em }} 535 \mathrm{~nm}\right)$ was measured every min in a microplate reader Synergy HT-Siafrt ${ }^{\mathrm{TM}}$. A blank without AAPH was included. The area under fluorescein decay curve was calculated (AUC) with the equation $\mathrm{AUC}=0.5+\mathrm{f} 1 / \mathrm{f0}+\mathrm{f} 2 / \mathrm{f0} \ldots . .+\mathrm{fi}-1 / \mathrm{f0}+0.5 \mathrm{fi} / \mathrm{f0}$, where $\mathrm{f}$ is the fluorescence value at a particular time. The scavenging $\%$ was calculated with the following equation:

Scavenging $\%=\left[\left(\mathrm{AUC}_{\mathrm{S}}-\mathrm{AUC}_{\mathrm{NC}}\right) /\left(\mathrm{AUC}_{\mathrm{B}}-\mathrm{AUC}_{\mathrm{NC}}\right)\right] * 100$

where, $\mathrm{S}$ is sample, B is blank, $\mathrm{NC}$ is negative control.

Scavenging of ABTS+ Radical. ABTS radical cation (ABTS+') discoloration assay was performed according to Siddhuraju [22] with some modifications [8]. Briefly, ABTS + was produced, diluted in water and equilibrated at room temperature to give an absorbance of $0.8 \pm 0.2$ at $734 \mathrm{~nm}$ (Beckman DU 650, USA spectrophotometer). $10 \mu \mathrm{L}$ of amaranth isolate and its hydrolysate solubilized at different concentrations were mixed with $990 \mu \mathrm{L}$ of ABTS + . solution, and absorbance at $734 \mathrm{~nm}$ was measured at different times $(0-120 \mathrm{~min})$. Trolox $(0.5-1.5 \mathrm{mmol} / \mathrm{L})$ was used as positive control, while buffer Tris $50 \mathrm{mmol} / \mathrm{L} \mathrm{pH} \mathrm{8,} \mathrm{was} \mathrm{used}$ as negative control. Scavenging $\%$ was calculated with the following equation:

Scavenging $\%=\left[\left(\mathrm{Abs}_{0}-\mathrm{Ab}_{\mathrm{St}}\right)-\left(\mathrm{Abc}_{0}-\mathrm{Ab}_{\mathrm{Ct}}\right) / \mathrm{Abc}_{0}\right] * 100$

where, $\mathrm{Ab}_{\mathrm{Ct}}$ and $\mathrm{Abc}_{0}$ are absorbance of the negative control at 10 and $0 \mathrm{~min}$, respectively. $\mathrm{Ab}_{\mathrm{St}}$ and $\mathrm{Abs}_{0}$ are absorbance of the sample at 10 and $0 \mathrm{~min}$, respectively.

Suspensions of the samples in the corresponding buffer 8 were prepared using the same conditions indicated in section Samples Characterization and protein content was determined by Lowry method [18]. Scavenging \% was plotted as a function of the protein content of the sample in order to obtain the mass of protein necessary to produce $50 \%$ of scavenging $\left(\mathrm{IC}_{50}\right)$.

\section{Statistical Analysis}

Isolates and hydrolysates were prepared three times at least. Data were analyzed by means of the analysis of variance (ANOVA) with the post-hoc least significant differences (LSD) Fisher test $(p<0.05)$.

\section{Results and Discussion}

\section{Incubation Conditions, Preparation, and Characterization of Amaranth Hydrolysate}

In order to produce a hydrolysate using the endogenous protease, incubation conditions of the isolate had to be determined (Fig. 1). Considering the fact that most of the antithrombotic and antioxidant peptides described in bibliography present low molecular masses [23], $\mathrm{pH}$, time and temperature conditions that produced major changes in the electrophoretic profiles were established as hydrolysis conditions of the protease.

Figure 1a shows an electrophoretic gel with profiles of samples incubated at different $\mathrm{pHs}$ for $3 \mathrm{~h}$ at $40{ }^{\circ} \mathrm{C}$. The isolate profile $(\mathrm{I}, \mathrm{pH} 7)$ presented bands of $56.6 \pm 0.9 \mathrm{kDa}$, $52 \pm 1 \mathrm{kDa}, 36 \pm 1$ and $31 \pm 1 \mathrm{kDa}$, and bands of molecular masses of $26.2 \pm 1.4,21.5 \pm 1.1$ and $20 \pm 1 \mathrm{kDa}$. As $\mathrm{pH}$ decreased from 7 to 2 , more drastic changes were observed in the profiles: 56 and $52 \mathrm{kDa}$ bands diminished in intensity or disappeared; at pH 3 the band of $52 \mathrm{kDa}$ was not observed, whereas $56 \mathrm{kDa}$ band was present even at $\mathrm{pH} 2.5$. The region of low molecular mass polypeptides was dyed more intensely as $\mathrm{pH}$ descended, due to the appearance of new low molecular mass bands that were not adequately separated in this gel (showed in tricine-SDS-PAGE, ESM2). A treatment at pH 2 was considered adequate to obtain the hydrolysate as its 
profile exhibited drastic changes and was the only one that did not contain the $36 \mathrm{kDa}$ band.

Figure 1b shows electrophoretic SDS-PAGE profiles of samples treated at different temperatures for $3 \mathrm{~h}$ at $\mathrm{pH} 2$. Even though proteolytic activity was observed in every sample, the profiles exhibited some differences. At 25 and $40{ }^{\circ} \mathrm{C}$ profiles resulted similar, the two bands with molecular masses near $20.1 \mathrm{kDa}$ disappeared in both profiles, but the treatment at $40{ }^{\circ} \mathrm{C}$ presented a lower quantity of high molecular mass bands. At 40,55 and $65{ }^{\circ} \mathrm{C}$ bands of 56 and $52 \mathrm{kDa}$ get cleaved, and numerous bands near $14.4 \mathrm{kDa}$ appeared in the inferior part of the those profiles. A treatment at $40{ }^{\circ} \mathrm{C}$ was considered adequate to obtain the hydrolysate as the highest extent of hydrolysis was reached when the sample was incubated at that condition.

Figure 1c presents electrophoretic SDS-PAGE profiles of samples treated at different times. As incubation time increased, new polypeptides appeared as a set of bands in the inferior zone of the gel and other bands of high molecular masses disappeared. At $1 \mathrm{~h}$ incubation the protease showed proteolytic activity, 56 and $52 \mathrm{kDa}$ bands disappeared from the profile. As hydrolysis progressed 36 and $31 \mathrm{kDa}$ bands diminished in intensity, profiles got more defined and in the region of low molecular mass, the intensity of the bands decreased indicating that those polypeptides were substrate of the enzyme, becoming even smaller. The electrophoretic profiles in Fig. 1c showed that a treatment at $16 \mathrm{~h}$ produces a hydrolysate more proteolyzed than those obtained at fewer incubation times. It must be taken into consideration that the changes of the isolate were generated not only by the protease activity, but also by the dissociating and denaturing effect of the acidic medium. Protonation of storage proteins promoted at acidic $\mathrm{pH}$ induces their unfolding and the dissociation of their quaternary structure with release of their subunits [24].

According to the results (Fig. 1a, 1b and 1c), the highest extent of hydrolysis was reached incubating for $16 \mathrm{~h}$ at $\mathrm{pH} 2$ and $40{ }^{\circ} \mathrm{C}$.

After determining proteolysis conditions, the hydrolysate was prepared from an Amaranthus hypochondriacus isolate. The activity of the endogenous protease was studied by measuring the degree of hydrolysis (DH\%) over time of the amaranth isolate using OPA method. Aliquots treated at $\mathrm{pH} 2$ and $40{ }^{\circ} \mathrm{C}$ were taken at different reaction times $(1,3,5,7$ and $16 \mathrm{~h}$ ) and $\mathrm{DH} \%$ was calculated. Figure $2 \mathrm{a}$ shows an increment of $\mathrm{DH} \%$ over time. After $7 \mathrm{~h}$ of incubation a decrease in the rate of hydrolysis was observed, maybe due to substrate depletion or to partial inactivation of the enzyme [25]. At $16 \mathrm{~h}$ of incubation the highest $\mathrm{DH} \%(5.3 \pm 0.4 \%)$ was reached. This result coincides with that observed in Fig. 1c, where the $16 \mathrm{~h}$ treatment sample showed more changes in the profile, when compared to the isolate, than the other samples. As the quantity of enzyme contained in the seeds remains unknown, the relation enzyme/substrate is not controlled and this may be a possible explanation for the low $\mathrm{DH} \%$ obtained.

The centesimal composition of the $\mathrm{H}_{\mathrm{EB}}$, compared with that of the isolate (I) is presented in Table 1. The composition of I was similar to that described by Condés et al. [26] and Sabbione et al. [9]. The hydrolysate showed a higher content of ashes, which came from the salt formed after acidification and neutralization of the sample, and also, a higher moisture content, probable because of the higher hydrophilicity of the peptides released during the hydrolysis (increase of amino and carboxyl groups). As a consequence, the protein content was lower than that of the isolate.

In order to visualize amaranth protein changes as a consequence of the hydrolysis, molecular mass variations were analyzed using molecular exclusion chromatography. Figure $2 b$ presents the chromatograms obtained for $\mathrm{I}$ and $\mathrm{H}_{\mathrm{EP}}$ divided in three zones: molecular masses $100 \mathrm{kDa}$ for zone I, between 5 and $100 \mathrm{kDa}$ for zone II, and $5 \mathrm{kDa}$ for zone III. The chromatogram of the isolate exhibited the presence of polymers in zone I that correspond to molecules of $\mathrm{P}$ and $11 \mathrm{~S}$ globulins of 280-360 kDa described by Martínez et al. [15] and to molecules of 7S globulin of 180-220 kDa, described by Marcone and Kakuda [27] and Quiroga et al. [28]. In zones II and III there were observed molecular species of $100 \mathrm{kDa}$, which probably correspond to albumins and dissociated subunits from globulins. Changes observed in the chromatogram profile of the hydrolysate when compared with the profile of the isolate confirm the fact that the protease generates important changes in the structure of the proteins. Table 1 shows the $\%$ area of the peaks in zones I, II and III. Unlike the chromatogram of the isolate, the chromatogram of $\mathrm{H}_{\mathrm{EP}}$ did not show the presence of any high molecular mass polymers in zone I, whereas the proportion of species increased in zones II and III. This could be due to the generation of lower molecular mass species from the high molecular mass ones, result supported in Tricine-SDS-PAGE gels (ESM2).

\section{Antithrombotic Activity}

Antithrombotic activity was evaluated using the microplate method described by Yang et al. [19], and modified by Zhang et al. [20]. The assay emulates last stage of blood coagulation, where thrombin hydrolyses fibrinogen generating fibrin monomers that subsequently polymerize. The ability to prevent total or partial formation of the fibrin clot is analyzed by looking at a diminution or total absence of turbidity at $405 \mathrm{~nm}$ in a microplate spectrophotometer.

Two mechanisms could be involved in the inhibitory action of the peptides contained in the sample. The first one is inhibition of thrombin, due to their binding to the active site or one of the exosites of the enzyme, thereby preventing the proteolysis of fibrinogen. The second one implies the presence of 
a

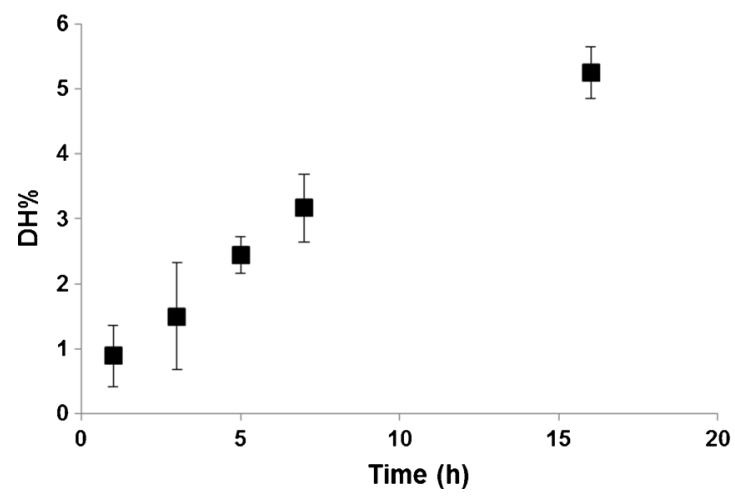

Fig. 2 a Hydrolysis evolution with time. Degree of hydrolysis (DH\%) of protein isolate obtained by acid activation of the endogenous Protease. error bars correspond to standard deviation. b FPLC chromatograms of protein isolate (solid line) and its hydrolysate (dotted line) solubilized in buffer $\mathrm{HNa}_{2} \mathrm{PO}_{4} 28 \mathrm{mmol} / \mathrm{L}, \mathrm{H}_{2} \mathrm{NaPO}_{4} 7 \mathrm{mmol} / \mathrm{L}$, pH 7.8 using a molecular exclusion column (Superose 6HR 10/30, elution range 5-

certain sequences capable of binding to fibrin monomers formed, preventing its polymerization [29].

Antithrombotic activity in vitro of the amaranth isolate and its hydrolysate was evaluated. The isolate did not exhibit clotting inhibition at the concentrations studied in this work $(0.17-12 \mathrm{mg} / \mathrm{mL})$. Figure 3a shows the inhibition curve obtained when $\mathrm{H}_{\mathrm{EP}}$ was used in the assay. The inhibition curve vs protein concentration presented dose-response behaviour; $\mathrm{H}_{\mathrm{EP}}$ showed clotting inhibition at $0.8 \mathrm{mg} / \mathrm{mL}$ and higher concentrations increased the inhibition reaching a plateau at approximately $13 \mathrm{mg} / \mathrm{mL}$. These data were processed with the GraphPad Prism program to calculate the $\mathrm{IC}_{50}$ of the sample, concentration that inhibits the $50 \%$ of the thrombus formation. The $\mathrm{IC}_{50}$ was $5.9 \pm 0.1 \mathrm{mg} / \mathrm{mL}$ (Table 2); this result verifies that the endogenous protease digestion, along with the acid treatment, released antithrombotic peptides or polypeptides, among others, that were initially encrypted in amaranth proteins.

The information gathered in bibliography shows that peptides with antithrombotic activity tend to be short [30, 31], though some peptides described present higher molecular masses $[32,33]$. Generally they correspond to peptides that

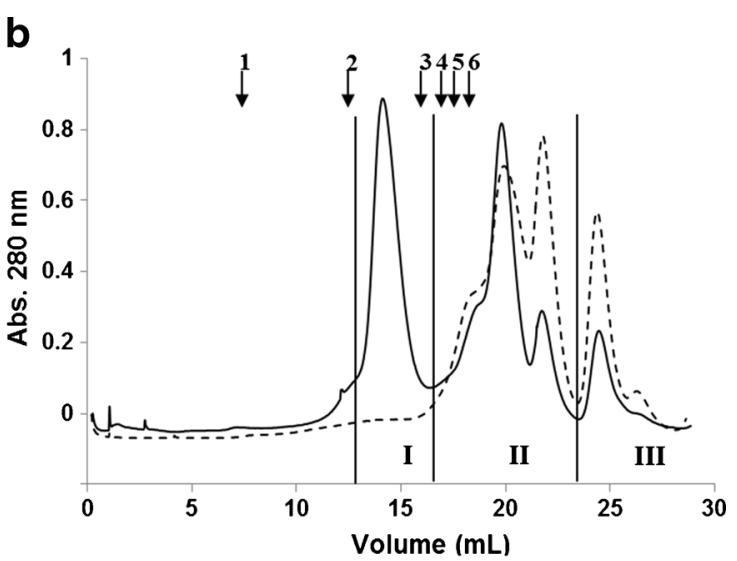

$5000 \mathrm{kDa}$ ). Elution volume and molecular mass standards are indicated with arrows (1: blue dextran, 2: thyroglobulin, 3: alcohol dehydrogenase, 4: albumin, 5: ovalbumin, 6: ribonuclease). Zones I, II and III include species with molecular masses $100 \mathrm{kDa}, 5-100 \mathrm{kDa}$, and $5 \mathrm{kDa}$, respectively

contain positively charged amino acids, such as arginine, in a defined position in their sequence. Notably, even though the hydrolysis degree reached by activating the protease resulted relatively low, the clotting inhibition of $\mathrm{H}_{\mathrm{EP}}$ proved to be higher when compared with that informed by Zhang et al. [20] and Yang et al. [19]. The authors reported inhibitory effects of $50 \%$ or more at concentrations between 20 and $30 \mathrm{mg} /$ $\mathrm{mL}$ for crude rapeseed peptides, and $>50 \mathrm{mg} / \mathrm{mL}$ for white egg hydrolysates. In a previous work [9], an $\mathrm{IC}_{50}$ value of $10.87 \pm 1.00 \mathrm{mg} / \mathrm{mL}$ was obtained when analyzing the antithrombotic activity of an Amaranthus mantegazzianus isolate hydrolyzed with two exogenous proteases, alcalase and trypsin. The hydrolysate obtained using an endogenous protease presented a higher activity when compared to those prepared in our laboratory by proteolysis of exogenous enzymes [9].

\section{Antioxidant Activity}

The ORAC assay studies the oxidative degradation of fluorescein after being mixed with free radical generators. This method measures the antioxidant capacity against the peroxyl radical, which damages the fluorescent molecule, resulting in the
Table 1 Centesimal composition of amaranth protein isolate (I) and of hydrolysate obtained by activation of endogenous protease $\left(\mathrm{H}_{\mathrm{EP}}\right)$. Percentage of areas in FPLC chromatograms

\begin{tabular}{|c|c|c|c|c|c|c|c|}
\hline & \multicolumn{4}{|c|}{ Centesimal composition (g/100 g sample) } & \multicolumn{3}{|c|}{$\begin{array}{l}\% \text { Area of the peaks in the different } \\
\text { zones of FPLC-molecular } \\
\text { exclusion chromatograms }\end{array}$} \\
\hline & Protein & Carbohydrates + fiber* & Ashes & Water & Zone I & Zone II & Zone III \\
\hline I & $82.4 \pm 1.6^{\mathrm{b}}$ & 10.3 & $2.4 \pm 0.1^{\mathrm{a}}$ & $4.9 \pm 0.2^{\mathrm{a}}$ & 39.7 & 50.1 & 10.2 \\
\hline $\mathrm{H}_{\mathrm{EP}}$ & $68.4 \pm 0.8^{\mathrm{a}}$ & 12.0 & $10.2 \pm 0.1^{\mathrm{b}}$ & $9.4 \pm 0.1^{\mathrm{b}}$ & 0 & 75.1 & 24.9 \\
\hline
\end{tabular}

Different superscripts letter in the same column corresponded at different values ( $p<0.05$, LSD)

*Carbohydrates + fiber were calculated by difference 
Fig. 3 Biological activities of isolate (I, square symbol) and its hydrolysate $\left(\mathrm{H}_{\mathrm{EB}}\right.$, circle symbol). a \% Clotting inhibition versus protein concentration. b Scavenging \% versus protein concentration, using ORAC and ABTS methods
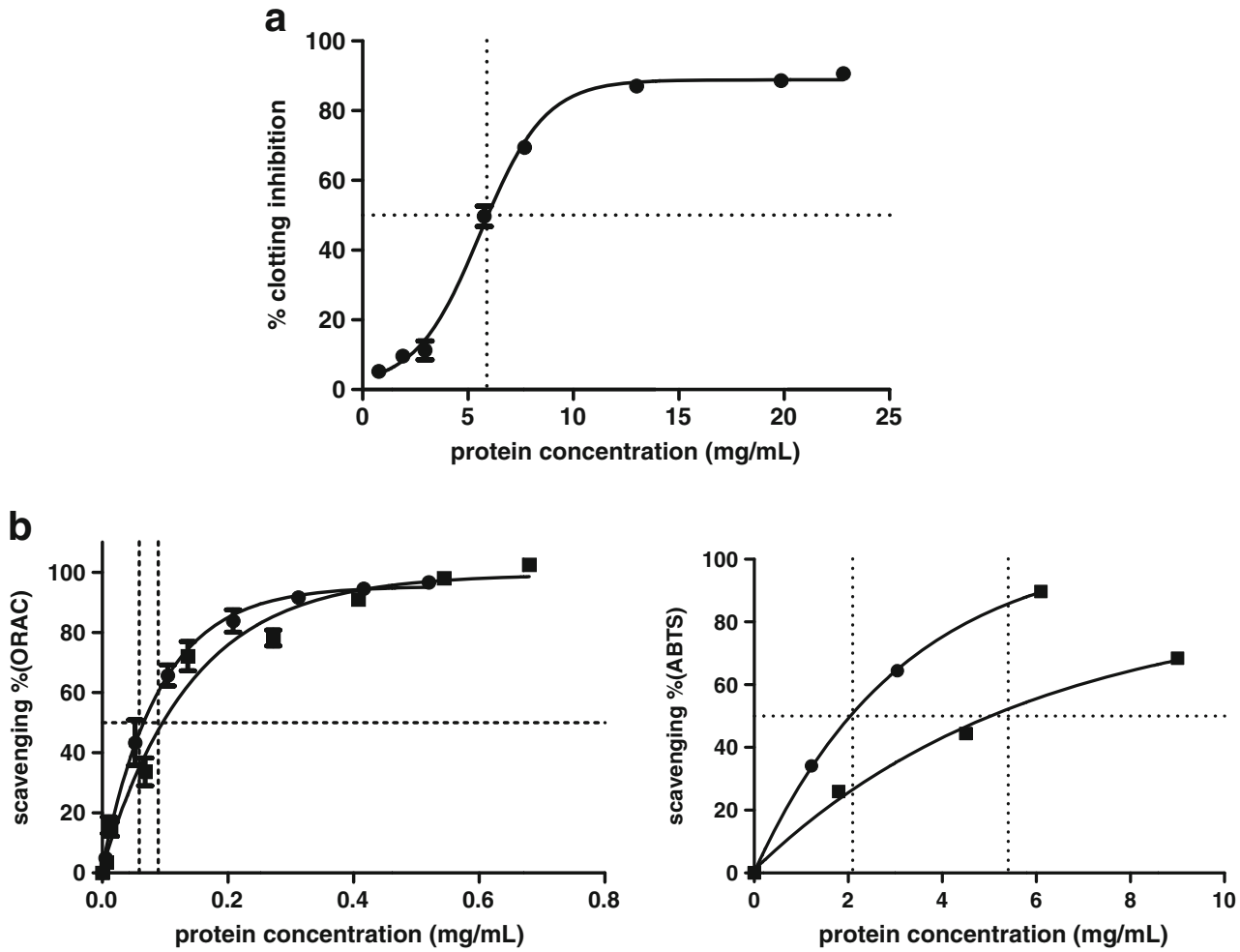

loss of fluorescence. Hence, compounds able to yield peroxyl radicals are considered antioxidants that protect the fluorescent molecule from the oxidative degeneration. Subsequently, the degree of antioxidant-mediated protection is quantified using the Trolox as a standard.

The ABTS method detects compounds able to yield hydrogen in order to neutralize the preformed free radical. The addition of antioxidants to the preformed chromophore radical cation reduces absorbance in a dependant manner to the antioxidant capacity of the sample, its concentration and exposure time [34]. Therefore, the discoloration degree associated with the antioxidant capacity depends on concentration and time, and it is usually expressed in relation to the reactivity of Trolox, a known antioxidant used as positive control in the same assay conditions.

Scavenging \% was calculated from measured values, which were plotted as a function of the protein concentration.
A dose-dependent activity was observed in the isolate and $\mathrm{H}_{\mathrm{EP}}$ curves (Fig. 3b) and these data were processed with the GraphPad Prism program to calculate $\mathrm{IC}_{50}$ values. Table 2 shows ABTS and ORAC $\mathrm{IC}_{50}$ values of the samples and Trolox; in both methods, the isolate and $\mathrm{H}_{\mathrm{EP}}$ exhibited antioxidant capacity.

ORAC results presented an $\mathrm{IC}_{50}$ value of the isolate $(0.102 \pm 0.021 \mathrm{mg} / \mathrm{mL})$ similar to that informed by Orsini Delgado et al. [21], whereas the $\mathrm{IC}_{50}$ of $\mathrm{H}_{\mathrm{EP}}$ $(0.058 \pm 0.027 \mathrm{mg} / \mathrm{mL})$ resulted higher when compared to other amaranth protein hydrolysates [21]. The values obtained in the ORAC assay did not show significant difference between the antioxidant capacity of the isolate and $\mathrm{H}_{\mathrm{EP}}$ (Table 2). In the ABTS assay the $\mathrm{IC}_{50}$ obtained for the isolate $(5.40 \pm 0.50 \mathrm{mg} / \mathrm{mL})$ was slightly lower than that previously informed by Orsini Delgado et al. [35] for isolates from A. mantegazzianus $(10.2 \pm 0.8 \mathrm{mg} / \mathrm{mL})$, whereas $\mathrm{IC}_{50}$ of
Table $2 \mathrm{IC}_{50}$ values for each biological activities of amaranth protein isolate (I) and hydrolysate obtained using acid conditions to activate an endogenous protease $\left(\mathrm{H}_{\mathrm{EP}}\right)$

\begin{tabular}{cccc}
\hline \multirow{2}{*}{$\begin{array}{c}\text { Antithrombotic activity } \mathrm{IC}_{50}(\mathrm{mg} / \mathrm{mL}) \\
\text { Microplate method }\end{array}$} & \multicolumn{2}{l}{ Antioxidative capacity $\mathrm{IC}_{50}(\mathrm{mg} / \mathrm{mL})$} \\
\cline { 3 - 4 } & not detected & $0.102 \pm 0.021^{\mathrm{a}}$ & $5.40 \pm 0.50^{\mathrm{a}}$ \\
\hline $\mathrm{I}$ & $5.90 \pm 0.10$ & $0.058 \pm 0.027^{\mathrm{a}}$ & $2.1 \pm 0.3^{\mathrm{b}}$ \\
$\mathrm{H}_{\mathrm{EP}}$ & Trolox & $0.0049 \pm 0.0001^{\mathrm{b}}$ & $0.38 \pm 0.05^{\mathrm{c}}$ \\
& & & ABTS method \\
\hline
\end{tabular}

Different superscripts letter in the same column corresponded at different values (p 0.05 , LSD)

$\mathrm{IC}_{50}$ : concentration of sample that inhibits the $50 \%$ of the thrombus formation or that produce $50 \%$ radical neutralization 
$\mathrm{H}_{\mathrm{EP}}$ resulted slightly higher $(2.1 \pm 0.3 \mathrm{mg} / \mathrm{mL})$ than amaranth hydrolysates obtained performing a simulated gastrointestinal digestion $(1.36 \pm 0.26 \mathrm{mg} / \mathrm{mL})$ and alcalase proteolysis during $4 \mathrm{~h}(1.44 \pm 0.03 \mathrm{mg} / \mathrm{mL})$ described by Orsini Delgado et al. [35]. In this assay a significant reduction of $\operatorname{IC}_{50}(p<0.05)$ was observed when comparing the isolate after and before activating the endogenous protease, indicating an increase in the antioxidant potency of $\mathrm{H}_{\mathrm{EP}}$ led by the proteolysis performed.

The samples studied are a blend of diverse components with different antioxidant potency, suggesting the existence of some species with high antioxidant activity. The bioactive peptides contained in the samples must be isolated and identified in order to achieve $\mathrm{IC}_{50}$ values comparable to Trolox.

\section{Conclusions}

The results obtained in the present study confirm the presence of an endogenous aspartic protease in an isolate of A. hypochondriacus (ESM1). This enzyme was active in a limited range of acid $\mathrm{pH}$ and a wide range of temperatures. Selected incubation conditions, $\mathrm{pH} \mathrm{2,40}{ }^{\circ} \mathrm{C}$ and $16 \mathrm{~h}$, generated a hydrolysate of $5 \mathrm{DH} \%$ which exhibited important structural differences in comparison with non-treated proteins. Confirming the results informed by Tironi and Añón [8], the isolate contained potential antioxidant peptides, whereas antithrombotic activity was not observed at the concentrations studied. The hydrolysate presented higher antioxidant and antithrombotic activity, indicating that the activation of the protease released bioactive peptides from amaranth proteins. Thereby, an amaranth hydrolysate which could be used as a potential functional ingredient, was obtained by using a simple and inexpensive process, such as decreasing the $\mathrm{pH}$.

Acknowledgments This work was supported by PIP - CONICET 11220110101109 .

\section{Compliance with Ethical Standards}

Conflict of Interest Authors, A.C. Sabbione, S.M. Ibañez, E.N. Martínez, M.C. Añón, and A. Scilingo, declare that they have no conflict of interest.

\section{References}

1. Hasler CM, Bloch AS, Thomson CA, Enrione E, Manning C (2004) Position of the American Dietetic Association: functional foods. J Am Diet Assoc 104:814-826

2. Martínez-Maqueda D, Miralles B, Recio I, Hernández-Ledesma B (2012) Antihypertensive peptides from food proteins: a review. Food Funct 3:350-361
3. Madureira AR, Tavares T, Gomes AMP, Pintado ME, Malcata FX (2010) Invited review: physiological properties of bioactive peptides obtained from whey proteins. J Dairy Sci 93:437-455

4. Kim SK, Wijesekara I (2010) Development and biological activities of marine-derived bioactive peptides: a review. J Funct Foods 2:1-9

5. Udenigwe CC, Aluko RE (2012) Food protein-derived bioactive peptides: production, processing, and potential health benefits. J Food Sci 77:11-24

6. Silva-Sánchez C, Barba de la Rosa AP, León-Galván MF, De Lumen BO, De León-Rodríguez A, González de Mejía E (2008) Bioactive peptides in amaranth (Amaranthus hypochondriacus) seed. J Agric Food Chem 56:1233-1240

7. López VRL, Razzeto GS, Escudero NL, Giménez MS (2013) Biochemical and molecular study of the influence of Amaranthus hypochondriacus flour on serum and liver lipids in rats treated with ethanol. Plant Foods Hum Nutr 68:396-402

8. Tironi V, Añón MC (2010) Amaranth as a source of antioxidant peptides: effect of proteolysis. Food Res Int 43:315-322

9. Sabbione AC, Scilingo A, Añón MC (2015) Potential antithrombotic activity detected in amaranth proteins and its hydrolysates. LWT-Food Sci Technol 60:171-177

10. Ventureira JL, Martínez EN, Añón MC (2012) Effect of acid treatment on structural and foaming properties of soy amaranth protein mixtures. Food Hydrocoll 29:272-279

11. Hemalatha KPJ, Siva Prasad D (2003) Changes in the metabolism of protein during germination of sesame (Sesamum indicum L.) seeds. Plant Foods Hum Nutr 58:1-10

12. Schaller A (2004) A cut above the rest: the regulatory function of plant proteases. Planta 220:183-197

13. Martínez EN, Añón MC (1996) Composition and structural characterization of amaranth proteins isolates. An electrophoretic and calorimetric study. J Agric Food Chem 44:2523-2530

14. Paredes-López O (1994) Amaranth: biology, chemistry and technology. CRC Press, Boca Raton, FL

15. Martínez EN, Castellani OF, Añón MC (1997) Common molecular features among amaranth storage proteins. J Agric Food Chem 45: 3832-3839

16. Schägger H (2006) Tricine-SDS-PAGE. Nat Protoc 1:16-22

17. Nielsen PM, Petersen D, Dambmann C (2001) Improved method for determining food protein degree of hydrolysis. J Food Sci 66: 642-646

18. Lowry OH, Rosebrough NJ, Farr AL, Randall RJ (1951) Protein measurement with the folin phenol reagent. J Biol Chem 193:265275

19. Yang WG, Wang Z, Xu SY (2007) A new method for determination of antithrombotic activity of egg white protein hydrolysate by microplate reader. Chin Chem Lett 18:449-451

20. Zhang S, Wang Z, Xu SY (2008) Antioxidant and antithrombotic activities of rapeseed peptides. JAOCS 85:521-527

21. Orsini Delgado MC, Galleano M, Añón MC, Tironi VA (2015) Amaranth peptides from simulated gastrointestinal digestion: antioxidant activity against reactive species. Plant Foods Hum Nutr 70: $27-34$

22. Siddhuraju P (2006) The antioxidant activity and free radicalscavenging capacity of phenolics of raw and dry heated moth bean (Vigna aconitifolia) (jacq.) marechal seed extracts. Food Chem 99: 149-157

23. Atanassov A, Tchorbanov B (2009) Synthetic and natural peptides as antithrombotic agents. A view on the current development. Biotechnol Biotechnol Equip 23:1109-1114

24. Abugoch LE, Martínez EN, Añón MC (2010) Influence of pH on structure and function of amaranth (A. hypochondriacus) protein isolates. Cereal Chem 87:448-453

25. Walsh R, Martin E, Darvesh S (2010) A method to describe enzyme-catalyzed reactions by combining steady state and 
time course enzyme kinetic parameters. Biochim Biophys Acta 1800:1-5

26. Condés MC, Scilingo A, Añón MC (2009) Characterization of amaranth proteins modified by trypsin proteolysis. Structural and functional changes LWT 42:963-970

27. Marcone MF, Kakuda Y (1999) A comparative study of functional properties of amaranth and soybean globulins isolates. Nahrung 43: 368-373

28. Quiroga AV, Martínez EN, Rogniaux H, Geairon A, Añón MC (2010) Amaranth (Amaranthus hypochondriacus) vicilin subunit structure. J Agric Food Chem 58:12957-12963

29. Laudano AP, Doolittle RF (1978) Synthetic peptide derivatives that bind to fibrinogen and prevent the polymerization of fibrin monomers. Proc Natl Acad Sci USA 75:3085-3089

30. Lee KA, Kim SH (2005) SSGE and DEE, new peptides isolated from a soy protein hydrolysate that inhibit platelet aggregation. Food Chem 90:389-394
31. Hyun KW, Jeong SC, Lee DH, Park JS, Lee JS (2006) Isolation and characterization of a novel platelet aggregation inhibitory peptide from the medicinal mushroom, Inonotus obliquus. Peptides 27: 1173-1178

32. Jo HY, Jung WK, Kim SK (2008) Purification and characterization of a novel anticoagulant peptide from marine echiuroid worm Urechis unicinctus. Process Biochem 43:179-184

33. Gan ZR, Gould RJ, Jacobs JW, Freidman PA, Polokoff MA (1988) Echistatin, a potent platelet aggregation inhibitor from venom of viper, Echis carinatus. J Biol Chem 263:19827-19832

34. Re R, Pellegrini A, Proteggente A, Pannala M, Yang C, RiceEvans C (1999) Antioxidant activity applying an improved ABTS radical cation decolorization assay. Free Radic Biol Med 26:1231-1237

35. Orsini Delgado MC, Tironi VA, Añón MC (2011) Antioxidant activity of amaranth protein or their hydrolysates under simulated gastrointestinal digestion. LWT 44:1752-1760 